Brit. J. industr. Med., 1953, 10, 9.

\title{
THE ACTION OF DIFFERENT FORMS OF PURE SILICA ON THE LUNGS OF RATS
}

\author{
BY \\ E. J. KING, Gi. P. MOHANTY, C. V. HARRISON, \\ and G. NAGELSCHMIDT \\ From the Postgraduate Medical School, London, and the Safety in Mines \\ Research Establishment, Sheffield
}

(RECEIVED FOR PUBLICATION AUgUST 1, 1952)

Pure silica $\left(\mathrm{SiO}_{2}\right)$ exists at room temperature in the four different modifications: quartz, tridymite, cristobalite, and fused silica. The first three are crystalline, but fused silica is a non-crystalline solid, a glass. Tridymite, cristobalite, and fused silica are metastable, but at room temperature they do not invert within measurable time to the only thermodynamically stable modification, quartz.

It can be regarded as proven that quartz can produce tissue changes in the lungs of animals similar to those found in human silicosis. It was also thought up to quite recently that silica was unique in producing such changes. Experiments with $r$ - and $l$ - quartz (King, Rogers, Gilchrist, and Nagelschmidt, 1945) had shown that there was no difference in the action of either of the optically active forms from the effect of the racemic type.

It was thought desirable next to test the effect of the four different modifications of silica under comparable conditions. The only previous information in this field came from Gardner (1938) who had injected rabbits by the ear vein with $1 \mathrm{~g}$. lots and had found progressive nodular fibrosis of the liver with quartz and fused silica, but a more severe diffuse fibrosis with cristobalite and a still more rapid reaction with tridymite which resulted in the death of all his animals within three months or less. Gardner stated that his samples were analysed and were all below 3 micron diameter, but he did not give any results of analyses or counts.

We decided to make comparable sized fractions of the four silica modifications and to use them for intratracheal injection into rats in order to study the effect of the crystal structure on the type and amount of tissue reaction.

*The cristobalite and tridymite were kindly supplied in 1946 by $\mathrm{Mr}$. E. H. M. Badger of the Gas, Light and Coke Co., now the Fulham Laboratory of the North Thames Gas Board, and the fused silica by Dr. A. E. F. Vickers of the Thermal Syndicate.
Description of Samples

Quartz.-This was prepared from a Belgian glass sand of high purity.

Cristobalite.* - Cristobalite was prepared by heating Loch Aline sand for one hour at $1620^{\circ} \mathrm{C}$. without using any flux.

Tridymite.*-Tridymite was prepared by dissolving the glassy impurities from a silica cement, which had had long service at approximately $1380^{\circ} \mathrm{C}$. in a gas retort house.

Fused Silica.-Fused silica was obtained from the Thermal Syndicate. It had been made from pure quartz crystals from Madagascar.

The Belgian glass sand contained $99.2 \%$ silica and the other materials $99.5 \%$ or more by chemical analysis.

Fractions below 2 microns were prepared from the four samples by repeated sedimentation in water. Before this was done the cristobalite, tridymite, and the fused silica were ground in a mechanically driven agate mortar.

Chemical analyses, solubilities, and size distributions of the samples are given in Table 1. Fig. 1A shows $x$-ray diffraction diagrams and $B, C, D$, and $E$ show electron micrographs of the samples. The diffraction diagrams agree with those given in the literature, and there is no indication of contamination by other silica modifications, except for the tridymite, which shows the strongest quartz line at $3.34^{\circ} \mathrm{A}$ as a very faint line, indicating 0.5 to $3 \%$ of quartz.

\section{Preparation of Dust Suspensions}

Amounts of $2 \mathrm{~g}$. of the individual dusts (fused silica, quartz, cristobalite, and tridymite) were weighed into $100 \mathrm{ml}$. conical flasks, and were mixed well with $60 \mathrm{ml}$. of sterile physiological saline. The final concentrations were thus $50 \mathrm{mg}$. of the individual dust in $1.5 \mathrm{ml}$. of suspension. These flasks were covered with rubber caps, and were sterilized by heating in a boiling water bath for 10 minutes on the day of the injections. 
TABLE 1

ANALYSIS AND PARTICLE SIZE DISTRIBUTION OF SAMPLES OF FREE SILICA

\begin{tabular}{|c|c|c|c|c|c|c|c|c|c|c|c|}
\hline \multirow{2}{*}{\multicolumn{4}{|c|}{ Size $(\mu)$}} & \multicolumn{2}{|c|}{ Fused Silica } & \multicolumn{2}{|c|}{ Quartz } & \multicolumn{2}{|c|}{ Cristobalite } & \multicolumn{2}{|c|}{ Tridymite } \\
\hline & & & & $\%$ by No. & $\%$ by Mass & $\%$ by No. & $\%$ by Mass & $\%$ by No. & $\%$ by Mass & $\%$ by No. & $\%$ by Mass \\
\hline $\begin{array}{l}0.45 \\
0.45-0.64 \\
0.64-0.90 \\
0.90-1 \cdot 30 \\
1 \cdot 30-1.80 \\
1 \cdot 80-2.60 \\
2 \cdot 60-3.60 \\
3 \cdot 60-5 \cdot 10\end{array}$ & $\begin{array}{l}\cdots \\
\cdots \\
\cdots \\
\cdots \\
\cdots \\
\cdots\end{array}$ & $\begin{array}{l}\ldots \\
\ldots \\
\cdots \\
\cdots \\
\cdots\end{array}$ & $\begin{array}{l}\cdots \\
\therefore \\
\cdots \\
\cdots \\
\cdots \\
\cdots\end{array}$ & $\begin{array}{l}37 \\
19 \\
17 \\
14 \\
8 \\
4 \cdot 8 \\
0 \cdot 2\end{array}$ & $\begin{array}{r}1 \cdot 9 \\
2 \cdot 7 \\
7 \cdot 2 \\
16 \cdot 0 \\
27 \cdot 0 \\
44 \cdot 5 \\
0.2\end{array}$ & $\begin{array}{c}26 \\
16 \\
18 \\
18 \\
14 \\
7 \cdot 8 \\
0 \cdot 2\end{array}$ & $\begin{array}{r}0.8 \\
1.6 \\
4.8 \\
13.5 \\
29.8 \\
46.4 \\
3.4\end{array}$ & $\begin{array}{l}32 \\
25 \\
23 \\
15 \cdot 5 \\
5 \cdot 7 \\
1 \cdot 65 \\
0 \cdot 15\end{array}$ & $\begin{array}{r}2 \cdot 4 \\
5 \cdot 2 \\
12 \cdot 1 \\
26 \cdot 3 \\
26 \cdot 1 \\
27 \cdot 6 \\
0 \cdot 3\end{array}$ & $\begin{array}{r}15 \\
13 \\
18 \\
27 \\
17 \\
9 \\
1\end{array}$ & $\begin{array}{r}0 \cdot 4 \\
1 \cdot 1 \\
4 \cdot 1 \\
17 \cdot 3 \\
31 \cdot 1 \\
45 \cdot 3 \\
0 \cdot 7\end{array}$ \\
\hline \multicolumn{4}{|c|}{ Particles counted .. } & \multicolumn{2}{|c|}{689} & \multicolumn{2}{|c|}{388} & \multicolumn{2}{|c|}{457} & \multicolumn{2}{|c|}{402} \\
\hline \multicolumn{4}{|c|}{ Surface area $\left(\mathrm{m}^{2} / \mathrm{g}.\right)$} & \multicolumn{2}{|c|}{2} & \multicolumn{2}{|c|}{1.9} & \multicolumn{2}{|c|}{$2 \cdot 6$} & \multicolumn{2}{|c|}{1.8} \\
\hline \multicolumn{4}{|c|}{$\begin{array}{l}\text { Silica solubility } \\
\text { (mg.SiO }\end{array}$} & \multicolumn{2}{|c|}{$14 \cdot 4$} & \multicolumn{2}{|c|}{$13 \cdot 7$} & \multicolumn{2}{|c|}{$13 \cdot 4$} & \multicolumn{2}{|c|}{$13 \cdot 1$} \\
\hline \multicolumn{3}{|c|}{$\begin{array}{l}\text { Analysis : } \mathrm{SiO}_{2} \\
\text { Ignition loss (\%) }\end{array}$} & $\cdots$ & \multicolumn{2}{|c|}{$\begin{array}{l}99 \cdot 4 \\
0 \cdot 16\end{array}$} & \multicolumn{2}{|c|}{$\begin{array}{r}98 \cdot 2 \\
1 \cdot 0\end{array}$} & \multicolumn{2}{|c|}{$\begin{array}{r}99 \cdot 3 \\
0.6\end{array}$} & \multicolumn{2}{|c|}{$\begin{array}{r}99 \cdot 2 \\
0.4\end{array}$} \\
\hline
\end{tabular}

Animals

Thirty male rats were used for each of the dusts. They were from Worcester white strain, and their average weight was $250 \mathrm{~g}$.

\section{Experimental Procedure}

The dust suspension was injected into the lungs of the animals intratracheally following the technique of Kettle and Hilton (1932), modified by Belt and King (1945), King, Gilchrist, and Rae (1947) and King, Harrison, and Ray (1949). The rats were anaesthetized lightly with ether and the trachea was exposed by blunt dissection. The flask containing the dust suspension was well shaken, and $1.6 \mathrm{ml}$. $(0.1 \mathrm{ml}$. allowed to be retained in the syringe) was withdrawn into a $5 \mathrm{ml}$. syringe to which a short sharp needle ( 1 in. $\times 28$ gauge $)$ was fitted. The syringe was then kept agitated until the time of injection to prevent sedimentation within it. To obtain a good dispersion of the dust into the lung alveoli the injections were made quickly and with a certain amount of force. The wound was closed by a single suture. There were no anaesthetic or postoperative deaths.

\section{Mortality of Animals}

During the course of the experiment 11 of the fused silica group animals died, 18 of the quartz, 19 of the cristobalite, and 20 of the tridymite.

One rat from each of the fused silica, quartz, and tridymite group and two from cristobalite were lost by cannibalism. There was a large number of deaths early in the experiments, especially in the quartz, cristobalite, and tridymite groups $(10,17$, and 18 deaths respectively within the first 120 days), so it was not possible to obtain exactly equal days of survival in all the experiments. However, sufficient intervals were maintained between the killings to extend all the experiments up to a year. At this time six rats remained alive in the fused silica group, and they were killed at intervals, extending the experimental period up to 450 days. 
i

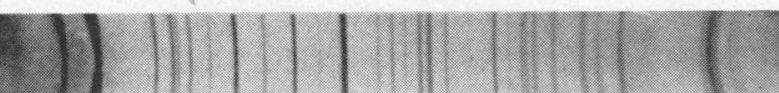

ii

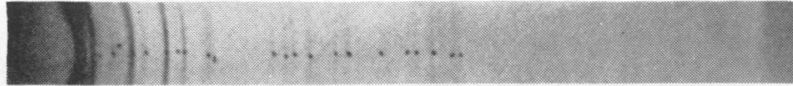

iii
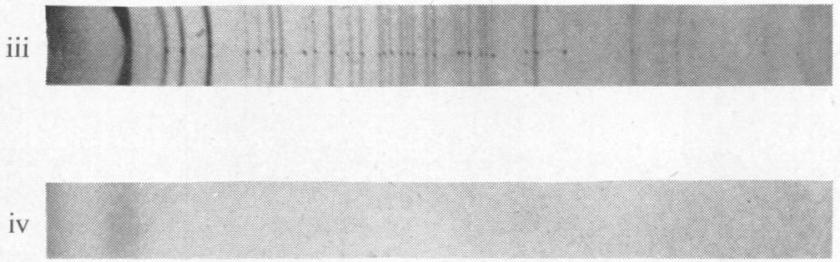

A

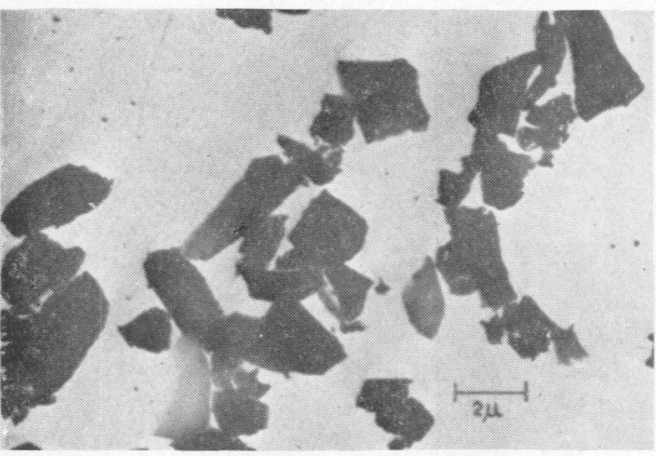

B

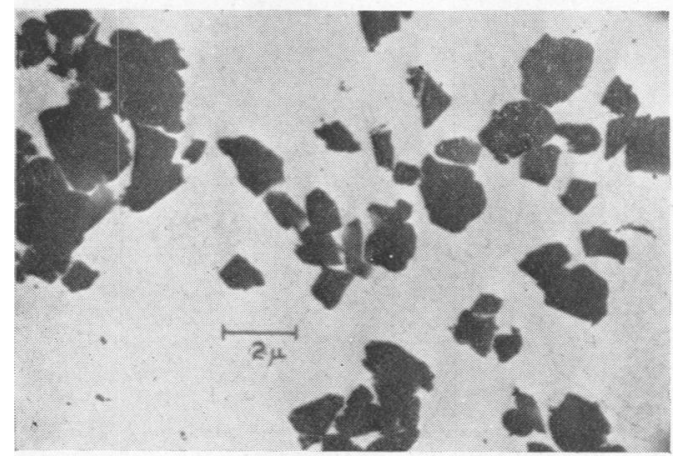

$\mathrm{D}$

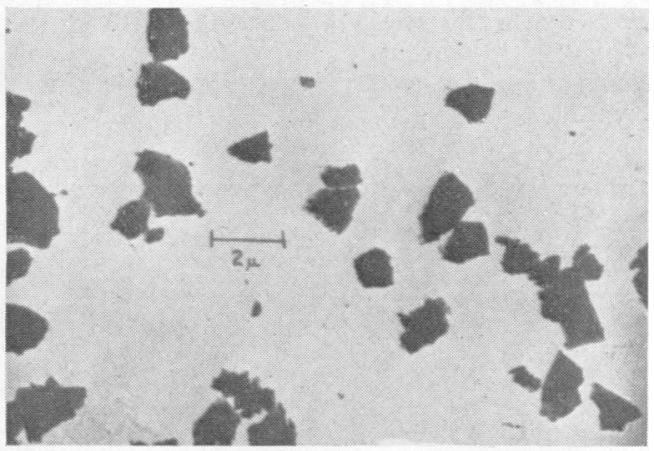

$\mathrm{C}$

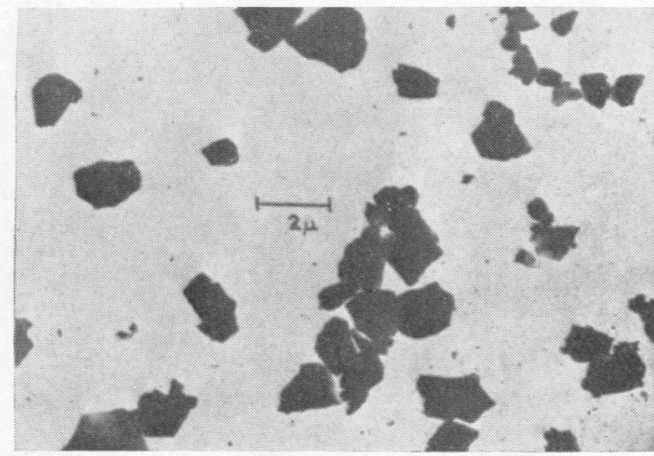

$\mathrm{E}$

FIG. 1.-(A) $X$-ray diffraction pattern of dusts : (i) quartz, (ii) tridymite, (iii) cristobalite, (iv) fused silica.

(B) Electron micrograph of the fused silica dust : (C) of quartz; (D) of tridymite ; (E) of cristobalite. $(\times 8,000$.)

greyish, firm, nodular areas. The lungs of the animals that died were dark and haemorrhagic, and the dust lesions were less prominent. Some of these animals had lung abscesses. (In a few cases the abscesses almost completely replaced the lung parenchyma and these animals were discarded 
from the series.) The tracheo-bronchial lymph nodes were enlarged to several times their normal size, and were firm and gritty.

\section{Microscopic Appearance of the Lungs}

Sections from the lungs of the rats were examined, and the pulmonary fibrosis seen in the most advanced lesions in each animal was graded according to Belt and King (1945). The pathological gradings so obtained, with the survival days of the killed animals, have been summarized in Table 2 .

The four different forms of free silica used in these experiments produced appreciably different reactions, both in rate and severity, in the lungs of the animals. The amorphous silica (fused silica) caused a moderate degree of pulmonary fibrosis (grade 3 maximal), which was less than that caused by the crystalline silica. Of the three different forms of crystalline silica, natural quartz produced the usual classical lung pathology. It showed a remarkably steady progression of the fibrosis as the experiment proceeded, and the maximum degree was attained by the ninth month. The two other conversion forms of quartz, cristobalite and tridymite, produced more severe and rapid fibrosis of the lungs. The tridymite was outstanding. It proved to be extremely pathogenic within a very short period, and the reaction produced was different. The fibrosis was more diffuse in character than nodular, probably because of the speed of its production, and the maximum degree (grade 5) was reached by the sixtieth day. The cristobalite was less toxic but caused a more rapid reaction than the quartz, the degree of fibrosis remaining always about one month in advance of that obtained with quartz (grade 5 in eight months).

TABLE 2

SUMMARY OF PATHOLOGICAL CHANGES IN THE LUNGS OF RATS PRODUCED BY DIFFERENT FORMS OF FREE SILICA

\begin{tabular}{|c|c|c|c|c|c|c|c|c|}
\hline \multirow{2}{*}{$\begin{array}{l}\text { Days of } \\
\text { Survival }\end{array}$} & \multicolumn{2}{|c|}{ Fused Silica } & \multicolumn{2}{|c|}{ Quartz } & \multicolumn{2}{|c|}{ Cristobalite } & \multicolumn{2}{|c|}{ Tridymite } \\
\hline & $\begin{array}{l}\text { Mode of } \\
\text { Death }\end{array}$ & $\begin{array}{l}\text { Grade of } \\
\text { Fibrosis* }\end{array}$ & $\begin{array}{l}\text { Mode of } \\
\text { Death }\end{array}$ & $\begin{array}{l}\text { Grade of } \\
\text { Fibrosis }\end{array}$ & $\begin{array}{l}\text { Mode of } \\
\text { Death }\end{array}$ & $\begin{array}{l}\text { Grade of } \\
\text { Fibrosis }\end{array}$ & $\begin{array}{l}\text { Mode of } \\
\text { Death }\end{array}$ & $\begin{array}{l}\text { Grade of } \\
\text { Fibrosis }\end{array}$ \\
\hline $1-30$ & $\begin{array}{l}\mathrm{D}(4) \\
\mathbf{K}(1)+\end{array}$ & $1 \mathrm{~min}$. & $\mathbf{K}(1)+$ & 1 & $\begin{array}{l}\mathbf{D}(1) \\
\mathbf{K}(1)+\end{array}$ & $2 \mathrm{~min}$. & $\begin{array}{l}\mathrm{D}(2) \\
\mathbf{K}(1)+\end{array}$ & $\begin{array}{l}1 \\
1\end{array}$ \\
\hline $31-60$ & $\mathbf{K}(1)$ & 2 & $\mathbf{K}(1)$ & 2 & $\begin{array}{l}\mathbf{D}(2) \\
\mathbf{K}(1)\end{array}$ & $3 \mathrm{~min}$. & $\begin{array}{l}\mathrm{D}(9) \\
\mathbf{K}(1)+\end{array}$ & $5 \mathrm{~min}$. \\
\hline $61-90$ & $\mathbf{K}(1)$ & 2 & $K(1)$ & 2 & $\begin{array}{l}\mathrm{D}(13) \\
\mathrm{K}(1)\end{array}$ & 1 & $\begin{array}{l}D(3) \\
K(1)\end{array}$ & $5 \mathrm{~min}$. \\
\hline $91-120$ & $\mathbf{K}(1)$ & $2 \max$. & $\begin{array}{l}\mathrm{D}(10) \\
\mathbf{K}(1)\end{array}$ & 3 & $\begin{array}{l}\mathbf{D}(2) \\
\mathbf{K}(1)\end{array}$ & $\begin{array}{l}1 \\
3\end{array}$ & $\begin{array}{l}\mathbf{D}(3) \\
\mathbf{K}(1)\end{array}$ & 5 \\
\hline $121-150$ & $\begin{array}{l}\mathrm{D}(1) \\
\mathbf{K}(1)+\end{array}$ & $2 \max$. & $\begin{array}{l}\mathbf{D}(3) \\
\mathbf{K}(1)+\end{array}$ & $\begin{array}{l}1 \\
3\end{array}$ & $\begin{array}{l}\mathbf{D}(1) \\
\mathbf{K}(1)+\end{array}$ & 3 & $\begin{array}{l}\mathbf{D}(1) \\
\mathbf{K}(1)\end{array}$ & 4 max. \\
\hline $151-180$ & $\begin{array}{l}\mathbf{D}(2) \\
\mathbf{K}(1)\end{array}$ & 2 & $\begin{array}{l}\mathbf{D}(1) \\
\mathbf{K}(1)\end{array}$ & $2 \max$. & $K(1)$ & 3 & $\begin{array}{l}\mathrm{D}(2) \\
\mathbf{K}(1)\end{array}$ & 5 \\
\hline $181-210$ & $\begin{array}{l}\mathbf{D}(1) \\
\mathbf{K}(1)\end{array}$ & 3 & $\begin{array}{l}\mathrm{D}(2) \\
\mathbf{K}(1)\end{array}$ & 3 & $K(1)$ & 3 & $\mathbf{K}(1)$ & 5 \\
\hline $211-240$ & $\mathbf{K}(1)$ & 1 & $\begin{array}{l}\mathbf{D}(1) \\
\mathbf{K}(1)\end{array}$ & 4 & $K(1)$ & 5 & & \\
\hline $241-270$ & $K(1)$ & 3 & $\begin{array}{l}\mathbf{D}(1) \\
\mathbf{K}(1)\end{array}$ & 5 & & & & \\
\hline $271-300$ & $\mathbf{K}(1)$ & 3 & $\mathbf{K}(1)$ & 5 & $K(1)$ & 4 & $K(1)$ & 5 \\
\hline $301-330$ & $\begin{array}{l}\mathbf{D}(1) \\
\mathbf{K}(2)+\end{array}$ & 3 & $\mathbf{K}(\mathbf{1})+$ & 5 & $\mathbf{K}(1)+$ & 5 & $\mathrm{~K}(1)+$ & 5 \\
\hline $331-365$ & $\begin{array}{l}\mathbf{D}(1) \\
\mathbf{K}(2)\end{array}$ & $3 \max$. & $K(1)$ & 5 & $K(1)$ & 2 & $\mathrm{~K}(1)$ & 5 \\
\hline $366-390$ & $\begin{array}{l}\mathbf{D}(1) \\
\mathbf{K}(2)\end{array}$ & 3 & & & & & & \\
\hline $391-420$ & $K(2)$ & 3 & & & & & & \\
\hline $421-450$ & $K(1)$ & 3 & & & & & & \\
\hline
\end{tabular}

+ Sections from these animals are reproduced in figures.

$\mathbf{K}=$ killed ; $\mathbf{D}=$ died ; the figure within brackets indicate number of deaths or killings during stated period.

Max. = maximal ; min. = minimal within the indicated group of fibrosis.

* Grade of maturity of fibrosis : 1, loose reticulin fibrils with no collagen; 2 , compact reticulin with or without a little collagen ; 3, somewhat cellular but made up mostly of collagen ; 4 , wholly composed of collagen fibres and completely acellular; 5 , acellular, collagenous, and confluent. 
In all cases there was subpleural drift of the dust, and pleural involvement, patchy over the underlying lesions, was seen in the form of sessile adhesions. Dust cells, singly or in small groups, were present in some alveoli ; pulmonary emphysema of mild degree was seen.

\section{Detailed Histological Findings}

Fused Silica.- This dust produced only a moderate degree of pulmonary fibrosis even though the experiment was extended beyond one year (see Table 2). The first animal that was killed, at the thirtieth day, showed a good dust cell reaction in the lungs; the dust-laden cells were diffusely scattered throughout the lung fields, and some were collected into small aggregations in certain perivascular and peribronchial regions. Occasionally, a slight increase of fine reticulin fibrils was seen within such nodular collections (grade 1 fibrosis minimal, Fig. 2). By the sixtieth day the nodules were well defined and composed mainly of fibroblasts. The reticulin fibres were thicker and more closely packed, with slight collagen formation in some nodules (grade 2 fibrosis). The animals, killed between this period and the 180th day, did not show any further advancement of the fibrosis than grade 2. At the 150th day the lesions appeared to be maximum within the limits of grade 2 fibrosis (Fig. 6). By the 210th day further progress of fibrosis was seen. The nodules were larger and irregular, some partly acellular, while a few others were only slightly cellular. The coarse reticulin fibres were tightly packed and arranged in the typical whorled pattern. The acellular areas were fully collagenous (grade 3 fibrosis). All the animals killed after this period up to the end of one year (except one at the 240th day which showed grade 1 fibrosis only) had similar lung lesions ; the fibrosis never exceeded grade 3 (Fig. 10). In the last one the lesions were a little advanced for grade 3 , but owing to their not being completely acellular they were assessed as grade 3 maximal. Free dust cells either singly or in small groups were seen in the lung fields of the majority of the animals. Some showed a good dust cell reaction within the hilar lymph

FIG. 2.-Rat lung 30 days after $50 \mathrm{mg}$. of amorphous silica (fused silica) dust. Nodules with very fine and loose network of reticulin fibres (grade 1 fibrosis, minimal). (Silver impregnation, $\times 100$.)

Fig. 3.-Rat lung 30 days after $50 \mathrm{mg}$. of quartz dust showing a nodule with fine and loose reticulin fibres within (grade 1 fibrosis). (Silver impregnation, $\times 100$.)

Fig. 4.- Rat lung 30 days after $50 \mathrm{mg}$. of cristobalite dust showing one large nodule near a bronchiole, with coarse and compact reticulin in the centre, but fine and loose at the periphery (grade 2 fibrosis, early). (Silver impregnation, $\times 100$.)
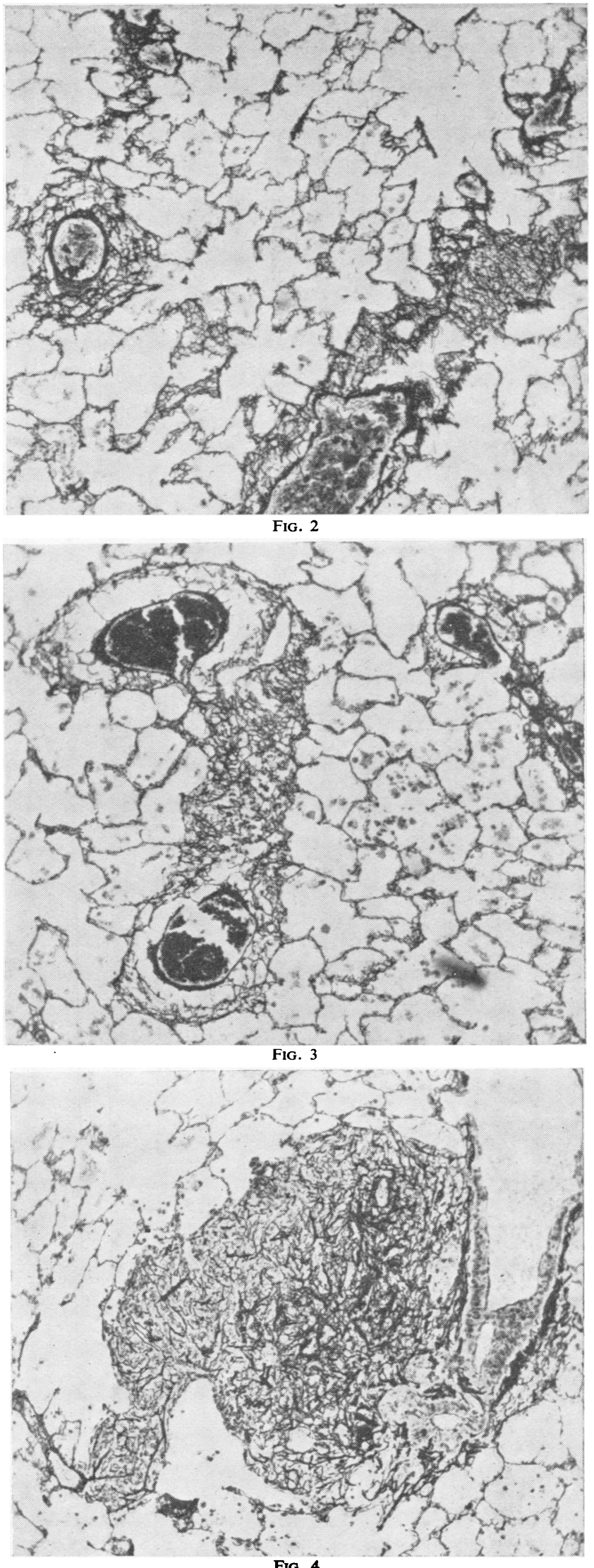


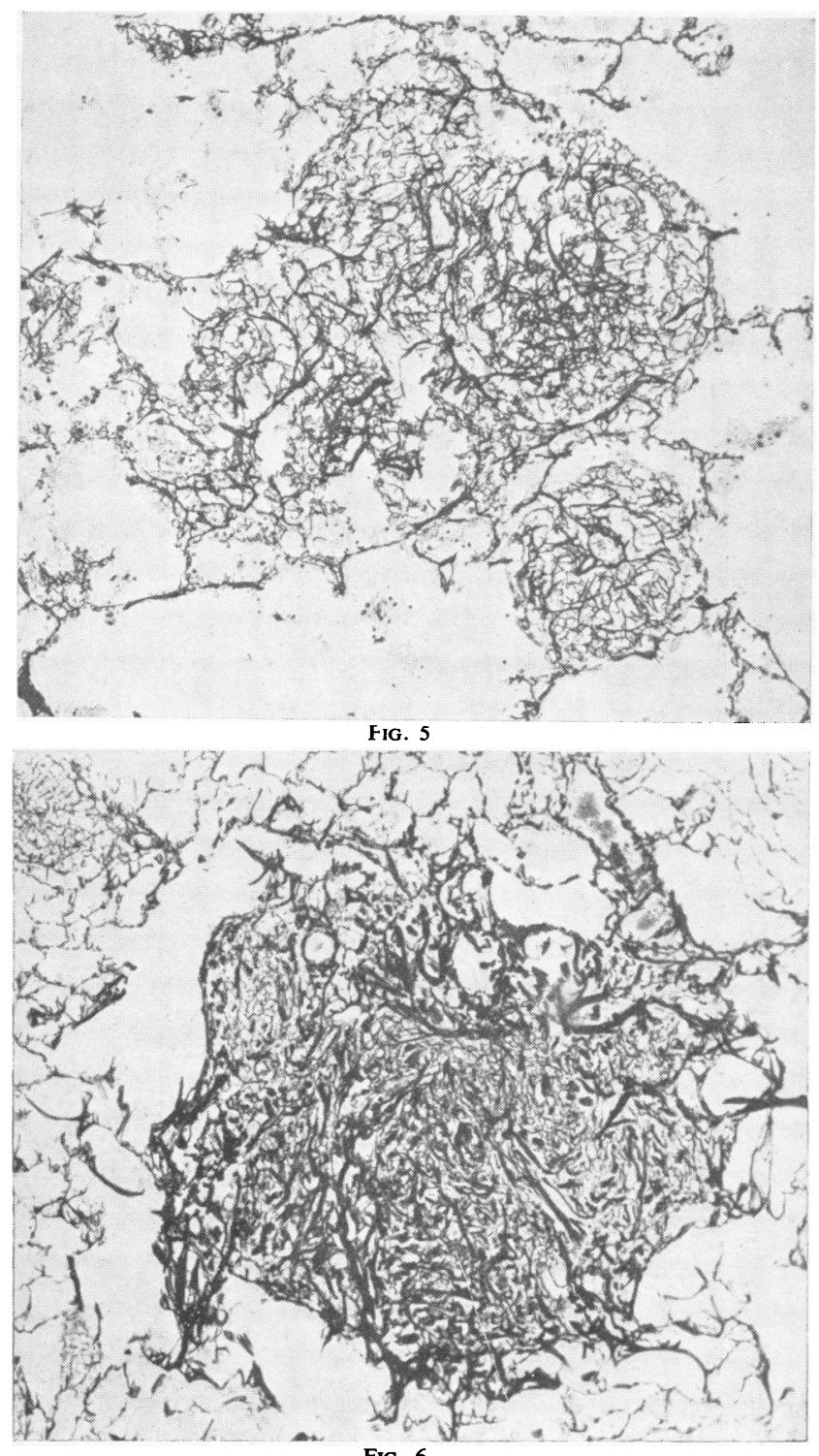

Fig. 6

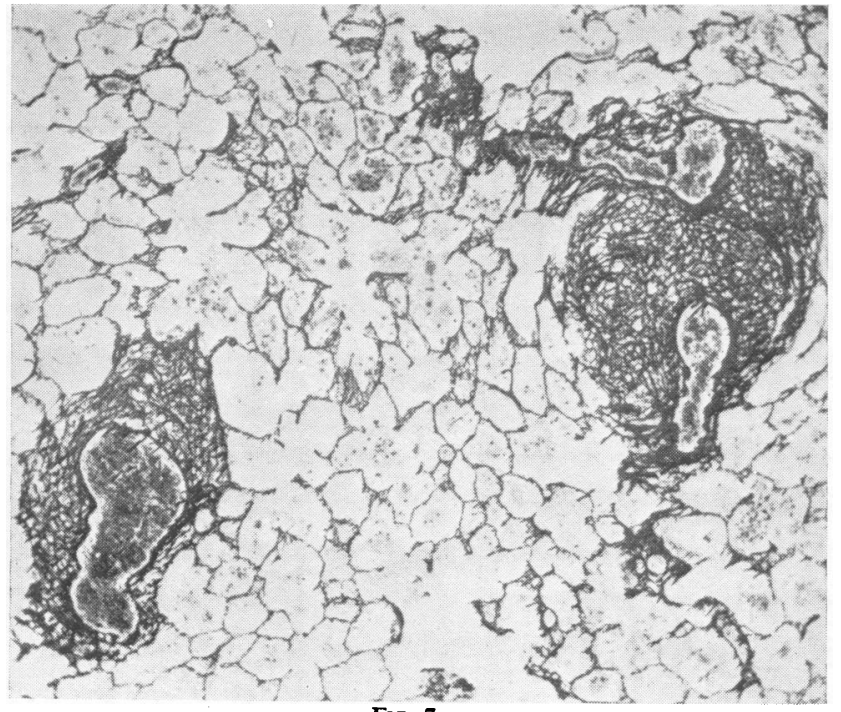

Fig. 7 nodes. Six animals remained at the end of a year and these were killed at intervals extending the experiment up to 450 days. None of them showed any further advance of fibrosis.

Quartz.-The quartz produced classical silicotic lesions in the lungs of the animals, with a steady progress in the degree of pulmonary fibrosis (summarized in Table 2). At the thirtieth day the lungs showed evenly distributed small, rounded collections of dust cells, mainly in relation to the smaller vessels and bronchioles, some intra-alveolar. The rest of the lung fields was clear, and no exudation was present. Reticulin fibres within these nodules were thick, but were tangled in a loose meshwork (grade 1 fibrosis, Fig. 3). In the lungs of the animal, killed at the sixtieth day, although presenting an almost similar histological picture, there were a few irregular and fibroblastic nodules. Within such nodules the reticulin fibres were coarse and dense, with a little collagen (grade 2 fibrosis). The fibrosis steadily progressed, so that, by the 120th day, the lesions became partly acellular, and more collagen replaced the reticulin tissue (grade 3 fibrosis). From the 120th day to the 210th day there was very little change in the pathology, beyond grade 3 fibrosis (Fig. 7). By the 240th day the nodules were completely acellular and fully collagenous, with a slight tendency in places to conglomerate (grade 4 fibrosis). All the rats killed after this period showed areas of confluent fibrosis, which were acellular and wholly collagenous (grade 5 fibrosis, Fig. 11). The subpleural drift of the dust was more marked in this group of animals than in others. The presence of free dust cells, dust cell reaction in hilar lymph nodes, and the degree of pulmonary emphysema were similar to those in the previous group.

Cristobalite.-Cristobalite induced slightly more rapid and severe changes in the lungs of animals than those produced by the quartz (see Table 2). The lungs of the first animal that was killed at the thirtieth day showed moderately large aggregations of dust cells. Fibroblasts appeared in some and the reticulin fibres within were coarse and more compact

Fig. 5.-Rat lung 30 days after $50 \mathrm{mg}$. of tridymite dust : a nodule composed of rather loose reticulin fibres which are denser and thicker towards the centre (grade 1 fibrosis). (Silver impregnation, $x$ 100.)

Fig. 6.-Rat lung 150 days after $50 \mathrm{mg}$. of amorphous silica dust showing one large nodule with coarse and compact reticulin and a few collagen fibres (grade 2 fibrosis). (Silver impregnation, ×65.)

FIG. 7.-Rat lung 150 days after $50 \mathrm{mg}$. of quartz dust showing almost fully collagenous silicotic nodules (grade 3 fibrosis). (Silver impregnation, $\times 65$ ) 
in the centre than at the periphery (grade 2 fibrosis, early, Fig. 4). Although the lesions were mainly in relation to vessels and bronchioles, some intraalveolar and subpleural nodules were present. The lesions progressed rapidly to the next stage, and by the sixtieth day a large number of large stellate partly cellular nodules were seen. Densely packed coarse reticulin was transformed in places to collagen fibres (grade 3 fibrosis). The animals killed between this period and the 210th day did not show in their lungs any further progress than grade 3 fibrosis (Fig. 8). A rapid progress of the lesions was then observed. By the 240th day large areas of acellular, collagenous, and confluent fibrosis of grade 5 were seen. Within such fibrotic areas some alveoli remained patent and a few new blood vessels were formed. In between confluent fibrotic areas some degree of pulmonary emphysema was present. Similar lung pathology was seen in the rest of the animals (grade 5 fibrosis, Fig. 12) except one at 365 days, wiich showed only grade 2 fibrosis. The pleura seemed to be more involved in this lung, large areas of highly thickened pleura being seen. Free dust cells were seen in the lung fields of most of the animals. Emphysema was noted earlier in this experiment.

Tridymite.-This dust appeared to be the most active of all in producing pulmonary fibrosis. Extremely severe lesions (grade 5 fibrosis) were produced as early as the sixtieth day, and all the animals killed after this showed similar changes in their lungs (see Table 2). By the thirticth day most of the dust cells were still scattered throughout the lung and there was an exudative reaction. The nodules were irregular, and fibroblasts appeared in the centres of some. Reticulin fibres were fine and loose in the periphery of such nodules, but the centres showed coarse and compact reticulin formation (grade 1 fibrosis, Fig. 5). These lesions progressed so rapidly that sections from the lungs of a rat on the sixtieth day showed completely acellular fully collagenous fibrosis. Almost all the nodules manifested a spreading character, encircling a bit of healthy lung tissue where emphysema was

FIG. 8.-Rat lung 150 days after $50 \mathrm{mg}$. of cristobalite dust showing almost fully collagenous nodules (grade 3 fibrosis). (Silver impregnation, $\times 65$.)

Fig. 9. - Rat lung 60 days after $50 \mathrm{mg}$. of tridymite dust showing fully collagenous confluent nodules with patent alveoli within some of them and pleural thickening (grade 5 fibrosis, early.) (Silver impregnation, $\times 65$.)

Fig. 10.-Rat lung 330 days after $50 \mathrm{mg}$. of amorphous silica dust, showing an almost fully collagenous subpleural nodule, pleural thickening and some degree of emphysema (grade 3 fibrosis) (Silver impregnation, $\times$ 40.)
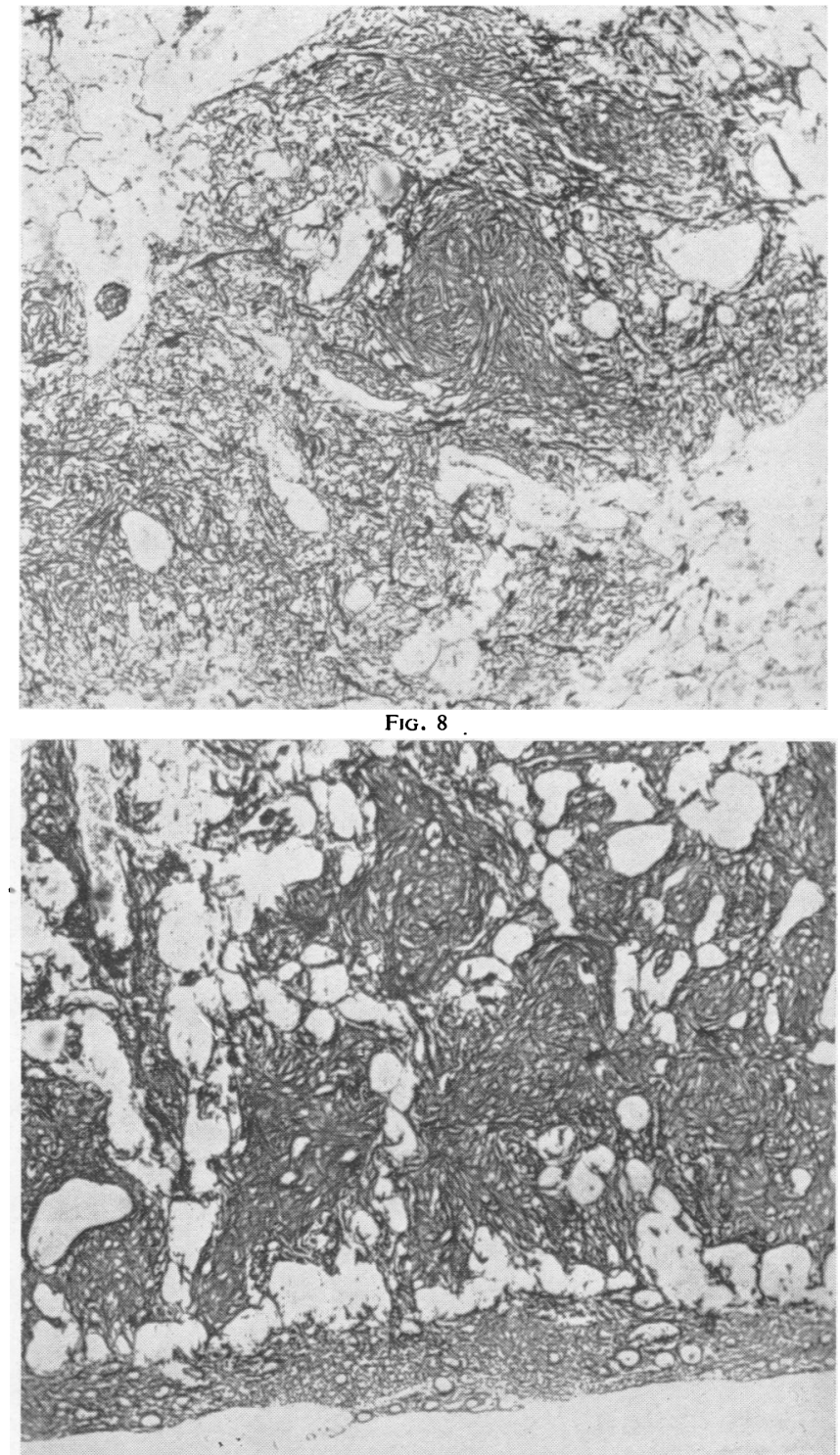

Fig. 9

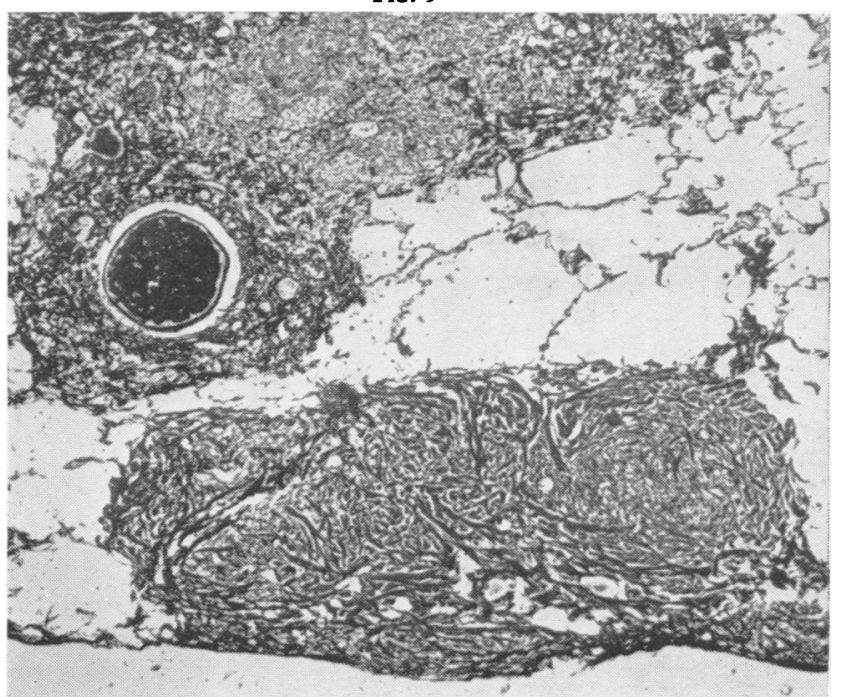

Fig. 10 


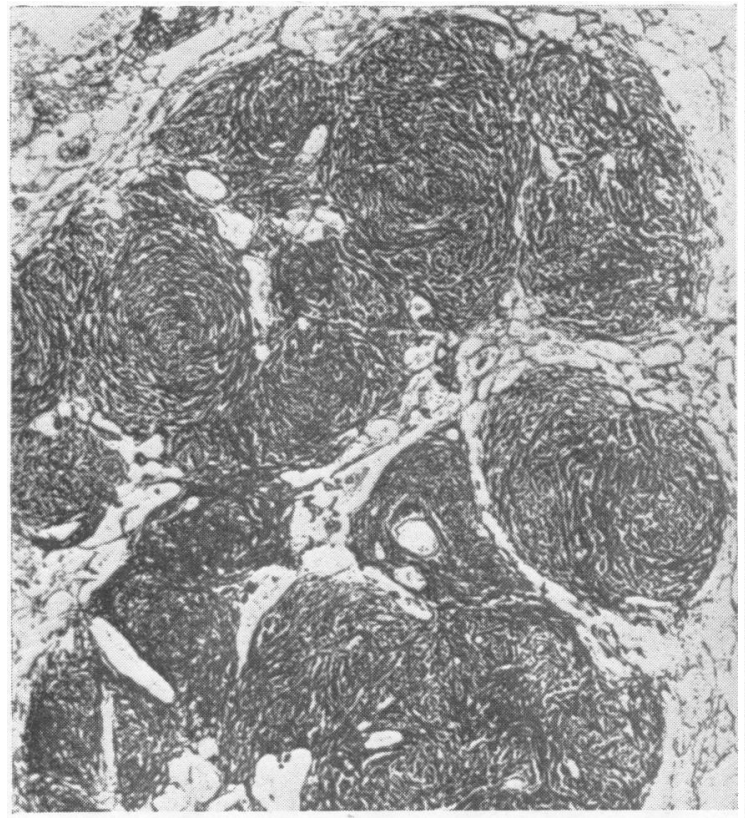

FIG. 11.-Rat lung 330 days after $50 \mathrm{mg}$. of quartz dust showing fully collagenous and confluent fibrosis (grade 5 fibrosis). (Silver impregnation, $\times$ 40.)

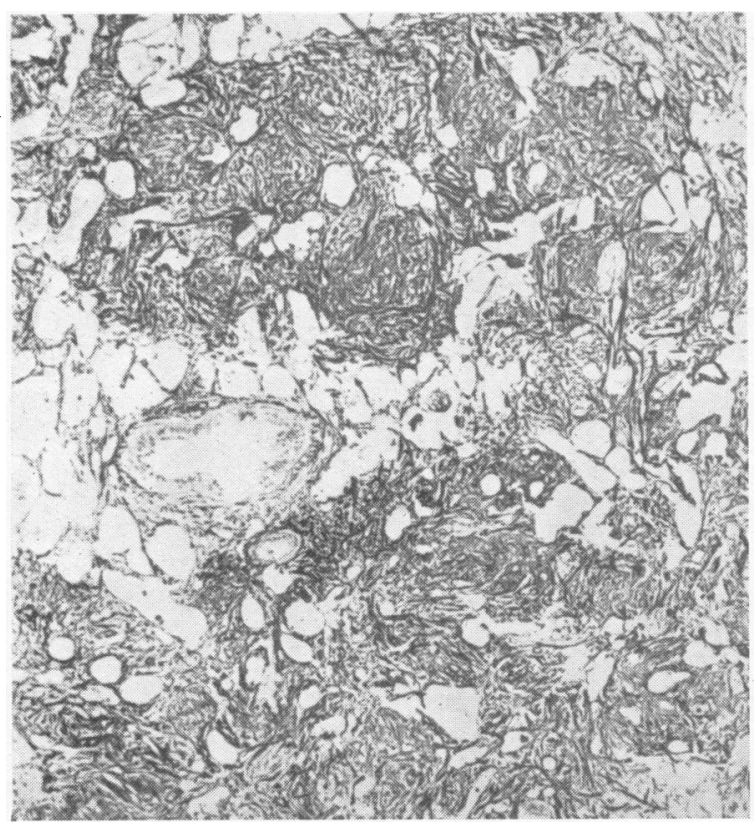

FIG. 12.-Rat lung 330 days after $50 \mathrm{mg}$. of cristobalite dust showing fully collagenous and confluent areas with patent alveoli within (grade 5 fibrosis). (Silver impregnation, $\times 40$.)

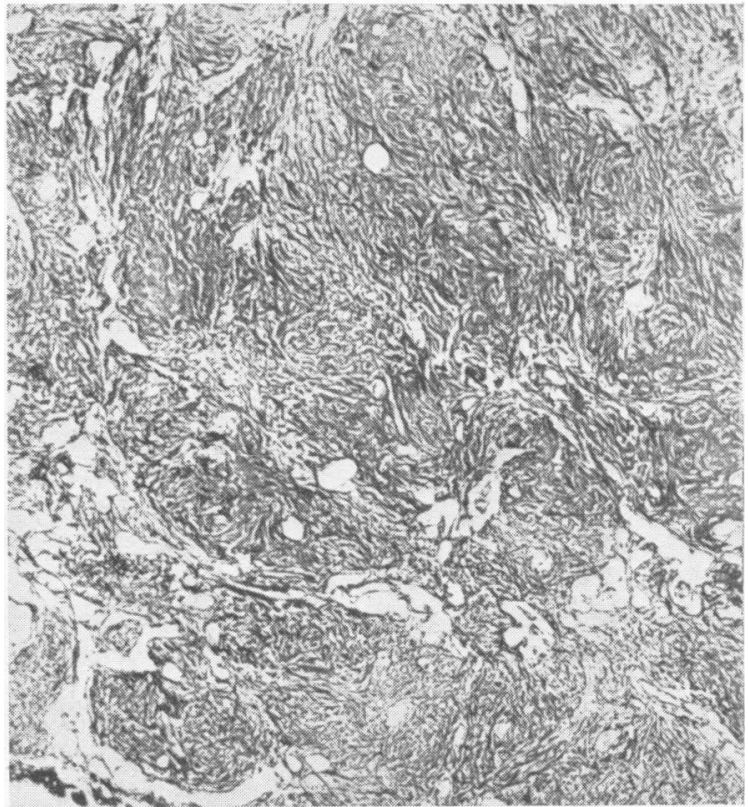

FIG. 13.-Rat lung 330 days after $50 \mathrm{mg}$. of tridymite dust showing fully collagenous confluent fibrosis of grade 5 involving the overlying pleura. (Silver impregnation, $\times 40$.)

seen (grade 5 fibrosis, early, Fig. 9). Formation of new blood vessels and central areas of necrosis were seen within some of the nodules. The pleura in most parts was thickened. All the animals killed subsequently showed similar changes ; and in some fibrosis involved a major part of the lung leaving very little healthy tissue (grade 5 fibrosis, Fig. 13).

\section{Discussion}

The results are best summarized by listing the shortest time intervals required to produce the various grades of fibrosis :

\begin{tabular}{|c|c|c|c|c|}
\hline \multirow{2}{*}{ Form of Silica } & \multicolumn{4}{|c|}{$\begin{array}{l}\text { Minimum Time (in Months) Required to } \\
\text { Produce Fibrosis of Grades 2-5 }\end{array}$} \\
\hline & 2 & 3 & 4 & 5 \\
\hline $\begin{array}{l}\text { Fused silica } \\
\text { Quartz } \\
\text { Cristobalite } \\
\text { Tridymite }\end{array}$ & $\begin{array}{l}2 \\
2 \\
1 \\
1\end{array}$ & $\begin{array}{l}7 \\
3 \\
2 \\
1 \frac{1}{2}\end{array}$ & $\begin{array}{l}\text { No further } \\
8 \\
7 \frac{1}{2}\end{array}$ & $\begin{array}{c}\text { change } \\
9 \\
8 \\
2\end{array}$ \\
\hline
\end{tabular}

The four pure silica modifications all had very similar silica solubilities and size distributions, and were injected in equal amounts of $50 \mathrm{mg}$. corresponding to about $1,000 \mathrm{~cm} .{ }^{2}$ of silica surface per rat. The resultant fibrosis varied considerably.

With fused silica there was no further progress beyond grade 3 within seven to 15 months. 
Quartz and cristobalite acted similarly. Grade 3 lasted from two or three months up to about seven or eight months and there was regular progression to grade 5 . The cristobalite acted perhaps slightly faster than the quartz, as all grades were reached about a month earlier.

The tridymite effect was spectacular. Grade 2 was reached after only one month, and grade 5 after two months. The fibrotic masses continued to grow, until in rats killed after 12 months there was hardly any normal lung tissue left.

These results suggest that the crystal structure of pure silica does influence the tissue reaction. Quartz, tridymite, cristobalite, and fused silica are built up from silicon-oxygen tetrahedra of equal size and shape. The tetrahedra share oxygen corners only. Each silicon is surrounded by four oxygens and each oxygen is bound to two silicons. The feature that varies is the arrangement of the tetrahedra in space, and the bond angles which two silicons make with the oxygen that is bound to both. The tetrahedra can be packed tightly, as in quartz which has a density of $2 \cdot 65$, or more loosely as in the other modifications which vary in density from $2 \cdot 2$ for fused silica to $2 \cdot 3$ for cristobalite. The arrangement is regular with a three-dimensional periodicity in the three crystalline modifications, and it is a random arrangement in fused silica. The crystal structures of cristobalite and tridymite are known in their main features but not in precise detail.

It is not possible to say why the different modifications act so differently, and in particular what causes the very strong reaction of the tridymite. A closer examination of a number of tridymite samples may give further information.

Silverman and Moritz (1950) made intraperitoneal injections of quartz and spherical fused silica into rabbits and found that the quartz gave a stronger fibrogenic reaction. They explained the difference by assuming that the quartz had a larger surface area. In view of Gardner's and our own findings this explanation is unconvincing, especially if it is remembered that the specific surface of their fused silica, as measured by a gas adsorption method, was actually over four times larger than the quartz surface.
In summarizing the evidence it can be said that there is reasonable qualitative agreement between the experimental results of Silverman and Moritz, of Gardner, and our own.

Vitreous silica is less active and tridymite much more active than quartz. Cristobalite is perhaps slightly more active than quartz.

\section{Summary}

Different forms of free silica, i.e. fused silica, quartz, cristobalite, and tridymite of high purity and equal size, were injected intratracheally into the lungs of rats to study any differences in the rate and severity of pathogenic reactions which they might produce. Of these, fused silica produced the least rapid pulmonary fibrosis, quartz the second, cristobalite the third, and tridymite was the most rapid in producing tissue reaction. In spite of their almost identical silica content, "size distribution, and silica solubilities, the crystalline modifications acted more rapidly than fused silica and there were marked differences between the crystalline forms. It seems probable that tissue activity is somehow related to the crystal structure of the dust, but this cannot as yet be explained.

The authors are indebted to Dr. D. Roberts, Mr. B. S. C. Hollands, and Mr. W. Weedon for help with the injection of the animals; Mr. Hollands for care of the animals, and cutting of the sections; Mr. J. Cartwright for the electron microscopy and diffraction; Mr. O. G. Griffin for the $x$-ray analyses, Miss N. Fowler for the microscopic size distribution, and Messrs. A. J. Beal and L. Mardlin for the chemical analyses. The photomicrographs are by Mr. E. V. Willmott.

Thanks are also due to the Medical Research Council for a grant towards the expenses of the investigation.

\section{REFERENCES}

Belt, T. H., and King, E. J. (1945). Spec. Rep. Ser. med. Res. Coun. Lond., No. 250.

Gardner, L. U. (1938). In Silicosis and Asbestosis, ed. Lanza, A. J., pp. 257-345. Oxford Unive sity Press, London. Kettle, E. H., and Hilton, R. (1932). Lancet, 1 1190.
King, E. J., Gilchrist, M., and Rae, M. V. (1947). J. Path. Bact., $59,324$.

59, Harrison, C. V., and Ray, S. C. (1949). Proc. 9th Int. Congr. Industr. Med., London. 1948, p. 666 . Bristol.

Industr. Meger, N., Gilchrist, M., and Nagelschmidt, G. (1945). J. Rogers, N., Gilchrist,

Silverman, L., and Moritz, A. R. (1950). Arch. indust. Hyg., 1, 499. 